UDC 332; DOI 10.18551/rjoas.2022-01.18

\title{
THE PERCEPTIONS OF RICE FARMERS IN IMPLEMENT THE CROPPING INDEX (CI) 200 APPLICATION AT RAINFED RICE FIELD TYPOLOGY IN MUARA ENIM REGENCY, INDONESIA
}

\author{
Arianti Triana Febi ${ }^{\star}$, Adriani Dessy, Aryani Desi \\ Faculty of Agriculture, University of Sriwijaya, Palembang, Indonesia \\ *E-mail: febyarianti.tfa@gmail.com
}

\begin{abstract}
The increasing of cropping index $(\mathrm{Cl})$ has contributed to an increase in rice production and regional food availibiality. The increasing of cropping index, especially in rainfed rice fields, has opened up opportunities for rice farmers to increase their income. However, there are still obstacles, so that $\mathrm{Cl} 200$ has not applied by all of rice farmers yet. The purpose of this research is to analyze rice farmers' perceptions fields in implement of IC 200. The research method used was a survey method while the sampling method used was Disproportionated Stratified Random Sampling where each level of stratification was represented by 50 farmers who applied $\mathrm{Cl} 200$ and 50 farmers who did not apply. The results of the study found that three indicators were in the agreed criteria, consisting of indicators of conformity with technical aspects, social factors, and benefits from economic aspects. On the other hand, the implementation risk indicator based on the results of a survey conducted was in the disagree criteria.
\end{abstract}

\section{KEY WORDS}

CI 200, rice, perception, farmers.

The food crops sub-sector has an important role in agriculture considering that food crops are a source of food for billions of the world's population. The development of superior food crop commodities will always exist and continue to increase due to the large contribution of food crops to life. Pusdatin (2019) explains that the cause of the high level of influence of food crops, especially rice on life, is that more than 50 percent of the world's population and 90 percent of Indonesia's population consume them as a staple food. The high consumption of rice for the Indonesian population is reflected in the average per capita rice consumption of the Indonesian population which reached $101.65 \mathrm{~kg} / \mathrm{capita} /$ year in 20022018. This level of rice consumption makes Indonesia the country with the third-largest rice consumption after China and India.

The magnitude of the influence of rice on life makes rice also become a political commodity whose existence and the price will affect economic and political stability. The effect of rice is the impact of the high consumption of rice for the Indonesian population, whose supply and the price will affect the economy. On the other hand, Indonesia's population reaches 255 million people with a growth rate of 1.31 percent per year where high levels of rice consumption require large amounts of food. The implication of the high consumption of national rice is the need to secure food availability by increasing rice production to meet the demands and needs of the community.

In realizing the policy of food sovereignty and increasing production of food crops, especially paddy (rice), the government has set a strategy to increase production through the implementation of the Upsus (Special Effort) program, such as rehabilitation of technical irrigation networks (JIT), land optimization, expansion of planting areas, and so on as agricultural development efforts. Regarding the expansion of the planting area, it is carried out through 1) printing of new land (rice fields); 2) land optimization by increasing the Planting Index (Cl); 3) optimization of other agricultural lands; and 4) optimization of abandoned land. One of the efforts that can be made to increase the production of food crops, especially rice in paddy fields, is technological innovation to increase the Cropping index $(\mathrm{Cl})$ both in irrigated and rainfed rice fields (BPTP South Sulawesi, 2018). 
The cropping index $(\mathrm{Cl})$ is the average planting and harvesting period in one year on the same land (BBP2TP Balitbangtan, 2018). The potential for increasing $\mathrm{Cl}$ in each region can be done through land optimization, especially those related to integrated management of water resources, climate, soil and nutrients, and improvement of cropping patterns. The Ministry of Agriculture through the Center for the Study of Agricultural Technology (BPTP) since 2017 has driven an increase in cropping intensity in their respective regions with a proportion of $70 \%$ in rainfed lowland land, $26 \%$ in the lowlands, and $4 \%$ in an upland dry land.

The increase in the rice cropping index also contributes to an increase in rice production and supports regional food security. Furthermore, the increasing index of rice cultivation has opened up opportunities for rice farmers to meet their family's food needs and income. Increasing the index of rice planting in rainfed rice fields is pursued through technological engineering (pumping, drilling wells), providing fertilizer assistance and certified early maturing seeds, as well as loan assistance for modern agricultural equClment such as jonder and combine harvesters so that soil processing time and harvest time can be carried out more efficiently and fast. However, various obstacles have been found since the introduction of $\mathrm{Cl} 200$ in Muara Enim Regency in 2016 so that the application of $\mathrm{Cl} 200$ has not been fully implemented by farmers. Based on this background, the purpose of this study was to find out how the perception of rice farmers towards the increase in the Cropping index (Cl) 200.

\section{METHODS OF RESEARCH}

This research took place in Muara Enim Sub District and Ujan Mas Sub District, Muara Enim Regency. The determination of the research location was carried out purposively with the consideration that the sub-district is an area that has the largest area of rainfed lowland rice in Muara Enim Regency and the most intensively implemented $\mathrm{Cl} 200$. The method used in this study was a survey method. The sampling method used was Disproportionated Stratified Random Sampling where each level of stratification is represented by 50 farmers who apply Cl 200 and 50 farmers who do not apply Cl 200 with a total sample of 100 farmers.

Data was collected through interviews and then analyzed using the tabulation scoring method and described descrCltively. All criteria for assessing farmers' perceptions of the increase in the index of rice cultivation in rainfed rice fields will be given a score as determined. To facilitate the assessment of respondents' answers, the criteria for category classes on a Likert scale are made which include: Strongly agree (4), Agree (3), Strongly Disagree (2), Disagree (1). The indicators used are compliance with technical aspects of the field, support for social factors, application risks, and benefits from the economic aspect. Each indicator in this case is measured using six questions and given a score.

According to Nasution (1998), the class interval formula can be made as follows:

$$
\begin{gathered}
N R=N S T-N S R \\
P I=N R: \text { JIK }
\end{gathered}
$$

Where: $\mathrm{NR}=$ range value, $\mathrm{NST}=$ highest score value, $\mathrm{NSR}=$ lowest score value, $\mathrm{PI}=$ interval length, JIK = the total of class intervals.

Thus, in calculating class intervals to measure indicators, the following formula can be used:

$$
\begin{aligned}
& \text { NST }=96 \text { ( } 4 \text { Indicators } \times 6 \text { questions } \times \text { weight of questions (4) } \\
& \text { NSR }=24 \text { ( } 4 \text { indicators } \times 6 \text { questions } \times \text { weight of questions (1) }
\end{aligned}
$$

$$
\mathrm{JIK}=4
$$


The calculations are as follows:

$$
\begin{gathered}
\mathrm{NR}=\mathrm{NST}-\mathrm{NSR}=72 \\
\mathrm{PI}=\mathrm{NR}: \mathrm{JIK}=18
\end{gathered}
$$

Furthermore, the class interval per indicator can be known as follows:

$$
\begin{gathered}
\text { NST = } 24 \text { ( } 6 \text { Questions } \times \text { weight of questions (4) } \\
\text { NSR = } 6 \text { ( } 6 \text { Questions } \times \text { weight of questions (1) } \\
\text { JIK }=4
\end{gathered}
$$

Calculation:

$$
\begin{gathered}
N R=N S T-N S R=18 \\
P I=N R: J I K=4.5
\end{gathered}
$$

Calculation of class intervals per question can be done as follows:

$$
\begin{aligned}
& \text { NST }=4 \text { (1 question } x \text { weight of questions (4) } \\
& \text { NSR }=1 \text { ( } 1 \text { question } \times \text { weight of questions (1) }
\end{aligned}
$$

Calculation:

$$
\begin{aligned}
& N R=N S T-N S R=3 \\
& P I=N R: J I K=0.75
\end{aligned}
$$

After the value between each class was obtained, the researchers measured the scores of all parameters of farmers' perceptions of the increase in the rice planting index in rainfed rice fields, Muara Enim Regency. The results obtained are presented in Table 1.

Table 1 - Class Interval Values for the Total Score of All Perception Measurement Parameters

\begin{tabular}{lllll}
\hline No & $\begin{array}{l}\text { The Score of Class Interval } \\
\text { (Total Score) }\end{array}$ & $\begin{array}{l}\text { The Score of Class Interval } \\
\text { (Per Indicator) }\end{array}$ & $\begin{array}{l}\text { The Score of Class Interval } \\
\text { (Per Question) }\end{array}$ & Criteria \\
\hline 1 & $24,00 \leq x \leq 42,00$ & $6,00 \leq x \leq 10,50$ & $1,00 \leq x \leq 1,75$ & Disagree \\
\hline 2 & $42,00 \leq x \leq 60,00$ & $10,50 \leq x \leq 15,00$ & $1,76 \leq x \leq 2,50$ & Less Agree \\
\hline 3 & $60,00 \leq x \leq 78,00$ & $15,00 \leq x \leq 19,50$ & $2,51 \leq x \leq 3,25$ & Agree \\
\hline 4 & $78,00 \leq x \leq 96,00$ & $19,50 \leq x \leq 24,00$ & $3,26 \leq x \leq 4,00$ & Strongly Agree \\
\hline
\end{tabular}

\section{RESULTS AND DISCUSSION}

Perceptions of increasing the Cropping index $(\mathrm{Cl})$ in rainfed rice fields in Muara Enim Regency can be defined as the direct response of farmers to an increase in the cropping index from one time to two times a year and whether the increase in $\mathrm{Cl}$ provides positive benefits for farmers. Perceptions of increasing $\mathrm{Cl}$ in rainfed rice fields in Muara Enim Regency were analyzed through four indicators, namely: Compliance with Technical Aspects, Support for Social Factors, Application Risks, and Benefits from Economic Aspects.

Measurement of suitability with technical aspects is carried out through several indicators related to the position of rice fields, irrigation systems, use of seeds, availability of fertilizers, and use of machine tools and modern agricultural technology. Assessment of technical aspects is presented in table 2 . 
On farmers' perceptions of the technical aspect of conformity indicators, it was found that on average the respondents gave a score of agreeing to 5 indicators and disagreeing on one indicator with a total score of 15.97. Farmers' perceptions of the technical aspects of the first indicator, namely the position of farmers' fields, have an average score of 2.67. This shows that most farmers agree that the rice fields they manage have a location or position that supports the implementation of $\mathrm{Cl}$ 200. It is known that not all rice fields support the implementation of $\mathrm{Cl} 200$ where in the dry season, the intensity of rain begins to decrease so that farmers' fields with higher positions will experience drought. In line in opinion Sutrisno et al., (2016) that rain-soaked rice fields and simple irrigation rice fields are generally constrained by inadequate water availability. In the rice fields, the availability of water to meet the water needs of plants is a determining factor in the sustainability of crop production and intensity.

Table 2 - Average Score of Farmers' Perceptions of Technical Aspects

\begin{tabular}{|c|c|c|c|c|c|c|c|c|}
\hline \multirow{3}{*}{ No. } & \multirow{3}{*}{ Indicator } & \multicolumn{7}{|c|}{ Assessment } \\
\hline & & \multicolumn{4}{|c|}{ Frequency } & \multirow{2}{*}{ Total Score } & \multirow{2}{*}{ Average } & \multirow{2}{*}{ Criteria } \\
\hline & & SS & $\mathrm{S}$ & KS & TS & & & \\
\hline 1. & The Position of Farmers' Field & 9 & 49 & 42 & - & 267 & 2.67 & $\mathrm{~S}$ \\
\hline 2. & The Irrigation System & 7 & 37 & 53 & 3 & 248 & 2.48 & S \\
\hline 3. & The Usage of Certified Seed & 2 & 66 & 32 & - & 270 & 2.70 & S \\
\hline 4. & The Availability of Subsidized Fertilizer & 12 & 46 & 41 & 1 & 269 & 2.69 & S \\
\hline 5. & The Usage of Agricultural tools and machinery & 27 & 44 & 29 & - & 298 & 2.98 & S \\
\hline 6. & The Technology of Modern Agriculture & 17 & 13 & 68 & 2 & 245 & 2.45 & KS \\
\hline Total & & 74 & 255 & 256 & 6 & 1597 & 15.97 & S \\
\hline
\end{tabular}

Note: Strongly Disagree (TS), Disagree (TS), Agree (S), Strongly Agree (SS). Primary Data Analysis (Processed), Primary Data Analysis (Processed).

In the second indicator, the irrigation system, the average farmer gave a score of 2.48 on the agreed criteria. This indicates that most of the irrigation systems in farmers' fields are adequate with sufficient water availability for the implementation of $\mathrm{Cl} 200$ with or without the help of engineering technology. From the information obtained at the research site, it was found that only a small number of farmers utilize engineering technology such as boreholes and pumping from other water sources. Most farmers still depend on rainwater to irrigate their fields. For this reason, the use of early maturing certified seeds is very necessary because the use of local varieties has a relatively longer planting age. This is in line with the perception assessment on the third indicator, namely the use of early maturing certified seeds, which has a score of 2.70 with the agreed criteria. This means that most farmers agree that certified rice seeds and their derivatives are sufficient and support the implementation of $\mathrm{Cl} 200$.

Perceptions on the fourth and fifth indicators are the availability of subsidized fertilizers and the use of agricultural machinery. On this indicator, the average farmer gave an agreed rating with a score of 2.69 and 2.98 , respectively. This shows that subsidized fertilizers are available, both in season I and season II. This is because the availability of subsidized fertilizers is adjusted to farmers' requests as stated in the Group Definitive Basic Plan (RDKK) which has been proposed since the previous year. Likewise for the fifth indicator, namely the use of machinery, where the average farmer gives an agreeable assessment. Farmers' assessments in this indicator indicate that most farmers, both those who implement $\mathrm{Cl} 200$ and farmers who do not implement $\mathrm{Cl} 200$, can access the agricultural machinery of government assistance managed by farmer groups.

In the last indicator, modern agricultural technology, most of the farmers gave a less agreeable answer with an average score of 2.45. Based on information obtained by researchers at the research site, it was found that not all farmers can access modern agricultural technology such as combine harvesters. This is because the rice harvest time is different while the number of combined harvesters is still limited. In addition, there are still many farmers who do not want to use a combined harvester because they still uphold local wisdom where harvesting is done through a cooperation system. 
The assessment of farmers' perceptions of social factor support is measured through six-component indicators consisting of instructor competence, extension intensity, farmer group management competence, social interaction, organizational activities, and support from the government which is fully presented in Table 3.

According to Hesthria (2018), the social aspect is a dynamic relationship between people, between people with groups, and between human groups. The social aspect is something that looks abstaking but still affects a person's life. In Table 3, it is presented that the average score of farmers' perceptions of factor support is 16.88. This result implies that most farmers agree with the support of social factors in the implementation of $\mathrm{Cl} 200$ in the research area. On the attributes of the first and second questions regarding the competence of the extension worker and the intensity of the extension carried out, the average farmer gave a score of 2.92 and 2.72 with the agreed criteria. This means that most farmers assume that field agricultural extension workers have the competence and are active enough to invite farmers to implement the $\mathrm{Cl} 200$. In the third indicator, namely the competence of farmer group administrators and social interaction with farmer groups, the average score given by farmers is 2.81 with the following criteria: agree. In other words, farmers perceive that farmer group administrators have sufficient capability to manage their farmer group and take an active role in inviting farmers to implement $\mathrm{Cl} 200$.

Table 3 - Average Score of Farmers' Perceptions of Support for Social Factors

\begin{tabular}{|c|c|c|c|c|c|c|c|c|}
\hline \multirow{3}{*}{ No. } & \multirow{3}{*}{ Indicator } & \multicolumn{7}{|c|}{ Assessment } \\
\hline & & \multicolumn{4}{|c|}{ Frequency } & \multirow{2}{*}{ Total Score } & \multirow{2}{*}{ Average } & \multirow{2}{*}{ Criteria } \\
\hline & & SS & $\mathrm{S}$ & KS & TS & & & \\
\hline 1. & Counselor Competence & 4 & 84 & 12 & - & 292 & 2.92 & $\mathrm{~S}$ \\
\hline 2. & Counseling Intensity & 6 & 60 & 34 & - & 292 & 2.72 & $\mathrm{~S}$ \\
\hline 3. & The Competence of Farmer Group Structures & 5 & 71 & 24 & - & 292 & 2.81 & $\mathrm{~S}$ \\
\hline 4. & Social Interaction & 22 & 68 & 10 & - & 292 & 3.12 & $\mathrm{~S}$ \\
\hline 5. & Organization Activity & 16 & 56 & 28 & - & 292 & 2.88 & $\mathrm{~S}$ \\
\hline 6. & The Government Support & - & 45 & 53 & 2 & 292 & 2.43 & KS \\
\hline Total & & 53 & 384 & 161 & 2 & 1.688 & 16.88 & $\mathrm{~S}$ \\
\hline
\end{tabular}

Note: Strongly Disagree (TS), Disagree (TS), Agree (S), Strongly Agree (SS). Primary Data Analysis (Processed), Primary Data Analysis (Processed).

According to Astriyani (2012), the competency of farmer group management is important in group management and management. funds to achieve the main goals of the group. In the social interaction component, the average score obtained is 3.12 with the agreed criteria. This means that the majority of farmers agree that most of the farmers in the research location are actively interacting. Through these social interactions, farmers can exchange information and experiences in agriculture. In the fifth question attribute, namely organizational activities, the average farmer gave a total agree with a score of 2.88. This shows that farmers have the same opinion that farmer groups are actively carrying out their functions as a bridge between farmers and the government as well as a forum for exchanging farmer information to solve problems in agriculture.

Table 4 - Average Score of Farmers' Perceptions of Implementation Risk

\begin{tabular}{|c|c|c|c|c|c|c|c|c|}
\hline \multirow{3}{*}{ No } & \multirow{3}{*}{ Indicator } & \multicolumn{7}{|c|}{ Assessment } \\
\hline & & \multicolumn{4}{|c|}{ Frequency } & \multirow{2}{*}{ Total Score } & \multirow{2}{*}{ Average } & \multirow{2}{*}{ Criteria } \\
\hline & & SS & $\mathrm{S}$ & KS & TS & & & \\
\hline 1. & The Courage of Taking Risk & 4 & 45 & 40 & 11 & 242 & 2.42 & KS \\
\hline 2. & Uncomfortable Feeling & 15 & 33 & 47 & 5 & 258 & 2.58 & S \\
\hline 3. & Not Done Yet By Many People & 40 & 50 & 10 & - & 330 & 3.30 & S \\
\hline 4. & Possibility of HPT Attact & - & 24 & 56 & 20 & 204 & 2.04 & KS \\
\hline 5. & Dry Risk & 1 & 29 & 68 & 2 & 229 & 2.29 & KS \\
\hline 6. & Risk of Harvest Failure & - & 19 & 70 & 11 & 208 & 2.08 & KS \\
\hline \multicolumn{2}{|c|}{ Total } & 60 & 200 & 291 & 48 & 1.471 & 14.71 & KS \\
\hline
\end{tabular}

Note: Strongly Disagree (TS), Disagree (TS), Agree (S), Strongly Agree (SS). Primary Data Analysis (Processed), Primary Data Analysis (Processed). 
In the last question component, namely government support, the majority of farmers gave a score of disagreeing with an average score of 2.43. This shows the farmer's opinion that the government has not provided sufficient guidance and encouragement for the implementation of $\mathrm{Cl} 200$. There were many obstacles found in the implementation of $\mathrm{Cl} 200$ such as the risk of drought and pest attacks which have been resolved independently by farmers.

In the research site, the risk of crop failure in the implementation of $\mathrm{Cl} 200$ during the dry season is quite high. In the dry season, the intensity of rain begins to decrease, making it vulnerable to drought. In addition to drought, pests attacks also tend to increase. The complete calculation of farmers' perceptions of the application risk indicators is presented in Table 4.

It is presented that the total score of farmers' perceptions of the risk of implementing $\mathrm{Cl}$ 200 is 14.71 , which means that the average farmer's perception of the risk of implementation is less agree. This is inseparable from the high risk faced by farmers in the implementation of CI 200 on SEASON II (Planting Time II) so that the results of rice production obtained are not as high as the implementation of $\mathrm{Cl} 100$ on SEASON I in the rain season. From the data obtained, the average score on the first indicator component, namely the courage to take risks, is 2.42 with the criteria of disagree. This score indicates that there are still many farmers who do not dare to take risks that might occur in the application of $\mathrm{Cl} 200$. The lack of courage to bear the business risks caused is the main factor why the implementation of $\mathrm{Cl}$ 200 is still not evenly distributed in the research location. For the second indicator component, namely discomfort, the average score is 2.58 with the criteria agreed. In this indicator, extra attention and treatment can overcome various problems that may arise during the implementation of $\mathrm{Cl} 200$. However, extra attention requires more funds so that the production costs incurred will also be higher.

Strengthening these findings, the average answer of farmers on the third indicator or the implementation of $\mathrm{Cl} 200$ has been carried out by many people is in agreement. This is evidenced by the average score of 3.30. This means that the implementation of $\mathrm{Cl} 200$ from year to year continues to increase. The increase in the planting index of 100 to the planting index of 200 began in 2016 and continues to this day. In the indicator component of the possibility of pest attacks, the total score obtained is 2.04 with the criteria of disagree. This indicates that the risk of plant pest attack is high, so extra attention is needed to prevent crop failure. The last indicator, namely the risk of drought and the risk of crop failure, farmers gave an average score of 2.29 and 2.08, respectively. The farmers' perception score on this indicator is relatively small compared to other indicators. Furthermore, this finding indicates that most farmers feel that the implementation of $\mathrm{Cl} 200$ so far is still at risk, both risks related to drought and pest attacks which ultimately lead to crop failure.

Benefit indicators viewed from the economic aspect are measured based on sixquestion components consisting of the expense, availability of capital, cost constraints, ease of access to marketing, the feasibility of selling price, and motivation to increase income. The complete calculation is presented in Table 5.

Table 5 - Average Score of Farmers' Perceptions of Benefit from Economic Aspects

\begin{tabular}{|c|c|c|c|c|c|c|c|c|}
\hline \multirow{3}{*}{ No } & \multirow{3}{*}{ Indicator } & \multicolumn{7}{|c|}{ Assessment } \\
\hline & & \multicolumn{4}{|c|}{ Frequency } & \multirow{2}{*}{ Total Score } & \multirow{2}{*}{ Average } & \multirow{2}{*}{ Ket } \\
\hline & & SS & $\mathrm{S}$ & KS & TS & & & \\
\hline 1. & Sacrifice Cost & 9 & 64 & 27 & - & 283 & 2.83 & $\mathrm{~S}$ \\
\hline 2. & Capital Availability & - & 74 & 23 & 3 & 271 & 2.71 & $\mathrm{~S}$ \\
\hline 3. & The Cost Hindrance & 8 & 51 & 41 & - & 267 & 2.67 & $\mathrm{~S}$ \\
\hline 4. & The Ease of Marketing Access & 5 & 89 & 6 & - & 299 & 2.99 & $\mathrm{~S}$ \\
\hline 5. & The Feasibility of Selling Price & 23 & 69 & 8 & - & 315 & 3.15 & SS \\
\hline 6. & The Motivation of Increasing Income & 30 & 53 & 17 & - & 317 & 3.17 & SS \\
\hline Total & & 75 & 400 & 122 & 3 & 1.748 & 17.48 & $\mathrm{~S}$ \\
\hline
\end{tabular}

Note: Strongly Disagree (TS), Disagree (TS), Agree (S), Strongly Agree (SS). Primary Data Analysis (Processed), Primary Data Analysis (Processed). 
According to Muharani (2019), the economic aspect is the underlying aspect of all activities related to the motive of getting money and using it as payment by farmers to get resources for their survival. Anything that guarantees the fullness of the needs of life, even provides opportunities or potentially generates income. Table 5. shows that farmers' perceptions of the benefits from the economic aspect are described by agreeing on answers with an average score of 17.48 . This shows that most farmers agree that the implementation of $\mathrm{Cl} 200$ provides benefits from the economic aspect. In the first indicator, namely the expense, the average score given by farmers is 2.71 with the criteria for agreeing. These results show the farmers' assumption that the results obtained from the implementation of $\mathrm{Cl}$ 200 are greater than the expense incurred.

The average scores on the second and third indicators, namely the availability of capital and cost constraints, are 2.71 and 2.67, respectively, with the agreed criteria. Based on this score, most of the farmers have sufficient capital where the costs incurred for the implementation of $\mathrm{Cl} 200$ are still considered reasonable. However, with this relatively reasonable cost, the rice production produced during the implementation of $\mathrm{Cl} 200$ in season II is not as much as rice production during the implementation of $\mathrm{Cl} 100$ in season I. Especially if the position of the farmer's rice fields is higher than the position of other rice fields so it is easier to happen drought. In addition, many farmers' rice fields are far from access to main roads and settlements, so the costs incurred for land preparation, maintenance and transportation are getting bigger.

The average score of farmers' perceptions regarding the ease of access to marketing and the feasibility of selling prices is 2.99 and 3.15 with the criteria agree and strongly agree. This means that there are no difficulties faced by farmers in selling their rice production. The information obtained by researchers in the field is that the selling price of $\mathrm{Cl} 200$ rice production is higher. However, most farmers prefer to sell their harvest directly rather than wait until prices are relatively stable after the main harvest. The marketing channel is relatively short, where farmers prefer to sell their crops at the rice mill in their village or to their neighbors around their house. The last indicator is the motivation to increase income where this indicator obtains an average score of 3.17 with the criteria of strongly agreeing. This means that most farmers agree that the majority of farmers are enthusiastic about implementing $\mathrm{Cl} 200$ as a way to increase their income even though there is no guarantee that there will be no crop failure.

Broadly speaking, farmers' perceptions of the increase in $\mathrm{Cl} 200$ are obtained by adding up the scores of indicators of suitability for technical aspects, support for social factors, implementation risks, and benefits from the economic aspects of respondents from rainfed rice farmers in Muara Enim Regency. From the sum of the total scores of the four indicators, it can be concluded that the farmers' perception of increasing the rainfed lowland rice cropping index from one planting season to two planting seasons in one year is on the agreed criteria. These results are presented in full in Table 5 below.

Table 6 - Total Score of Farmers' Perceptions of Increasing Cl

\begin{tabular}{llll}
\hline \multirow{2}{*}{ No. } & Indicator of Farmers' Perception & \multicolumn{2}{l}{ Achievement } \\
\cline { 3 - 4 } & & Score & Criteria \\
\hline 1 & The Suitability of Technical Aspect & 15.97 & Agree \\
2 & The Support of Social Factor & 16.88 & Agree \\
3 & The Risk of Implementation & 14.71 & Less Agree \\
4 & The Utilization of Economical Aspect & 17.48 & Agree \\
\hline Total Score & 65.04 & Agree \\
\hline
\end{tabular}

Source: Primary Data (Processed).

Table 6 shows that the total perception score of rainfed rice farmers in Muara Enim Regency on increasing $\mathrm{Cl} 100$ to $\mathrm{Cl} 200$ is 65.04 on the agreed criteria. Meanwhile, the total score on the indicators of conformity to technical aspects and social factors are 15.97 and 16.88, respectively where both indicators are being on agreed answers. Furthermore, the total score on the implementation risk indicator is 14.71 with the criteria of not agreeing. The 
usefulness indicator from the economic aspect obtained a total score of 17.48 with the agreed criteria. This finding indicates that broadly speaking, rainfed rice fields in Muara Enim Regency and their supporting factors are technically compatible where social factors support the implementation of $\mathrm{Cl} 200$ and are economically valuable for farmers who apply it. Apart from all the positive findings obtained, it was also found that the application of $\mathrm{Cl} 200$ still carries a risk of uncertainty from various factors, for example, due to the threat of pest attack and the risk of drought which can cause crop failure. This is in line with the research conducted by Adriani et al, (2019) where he stated that there were still various obstacles in the implementation of the $\mathrm{Cl} 200$ program that increased the risk of farming.

\section{CONCLUSION}

Most of the farmers' perceptions of the 200 Cropping index are in the agreed criteria as evidenced by the total score of 65.04 .

Three indicators are in the agreed criteria, including conformity with technical aspects, social factors, and benefits from economic aspects. Meanwhile, the implementation risk indicator is in the disagree criteria.

Farmers' participation in the implementation of IP 200 is still constrained by the high cost of engineering technology to overcome the problem of irrigation due to reduced rain intensity and the susceptibility of OPT attacks. The AUTP program that runs so far as a safety net for farmers has not been able to help optimally because there is often a default due to technical problems, the role of the government to control it is expected that farmers have guarantees on the implementation of IP 200.

\section{REFERENCES}

1. Adriani, D., E. Wildayana., I. Alamsyah., and A. Minha. 2019. Farmers' Performance and Determinants in Decisions to Adopt Innovations in Swamp Rice Planting Systems in South Sumatera. Journal of Sub Optimal Land 8 No 2 181-191.

2. Agricultural Data Center and Information System. 2019. Food Consumption Bulletin: Secretariat General of the Ministry of Agriculture. Vol 10 No.1 of 2019.

3. Assad, M., S. Banniek., Warda., and Z. Abidin. 2017. Analysis of Farmers' Perceptions of those who apply Jajar Legowo Planting for Paddy Rice in Southeast Sulawesi. Journal of Agricultural Technology Assessment and Development Vol 20. No. 03 November 2017 ISSN: 197-208.

4. Astriyani. 2012. The Performance of Field Agricultural Extension Officers (PPL) in Improving Farmer Competence in the Implementation of Rural Agribusiness Development (PUAP) in Indralaya District, Ogan Ilir Regency. Essay. Sriwijaya University Faculty of Agriculture. (Unpublished).

5. Center for the Study of Agricultural Technology (BPTP) South Sulawesi. 2018. Technological Innovation Supports Rice Planting Index (Cl).

6. Hestria, N. 2018. Impact of Corn Upsus Program on Increasing Production and Income of Corn Farmers in Tanjung Lago District of Banyuasin Regency. Thesis. Graduate Program of Sriwijaya University, Palembang.

7. Muharani, L. 2019. Analysis of Sustainable Palm Oil Plantation Assessment in Rimau Island District of Banyuasin Regency. Thesis. Graduate Program of Sriwijaya University, Palembang.

8. Nasution. 1998. Research Method (Scientific Research). Bumi Aksara. Jakarta.

9. Research Center for Agricultural Technology (BPTP) Balitbangtan. 2018. BPTP Balitbangtan Hastens to Increase the Planting Index in its Region. (Online, accessed January 3, 2020).

10. Sutrisno, N., A. Hamdani., H. Sosiawan. 2016. Water Resource Management Supports The Improvement of Rice Land Index. Agroclimat and Hydrological Research Center. Jakarta. 